artificial pollination was carried out. Seeds optimally germinated on Murashige and Skoog medium to 50\% with activated charcoal (AC) and Knudson $\mathrm{C}$ with $\mathrm{AC}$ and $1 \mathrm{mg} / \mathrm{L}$ of NAA, GA3, and kinetin.

\title{
Orquideas de los bosques de niebla del suroccidente de Colombia y oportunidades para su conservacion
}

\author{
Jorge Orejuela-Gartner
}

Universidad Autónoma de Occidente, Grupo de Estudios Ambientales para el Desarrollo Sostenible-GEADES, Km2 Vía Panamericana, Cali, Colombia; jeorejuela@uao.edu.co

Basado en inventarios realizados en bosques de niebla del suroccidente colombiano, en los departamentos de Nariño, Valle del Cauca y Antioquia, se se reporta un total de 420 especies de 85 géneros; una concentración marcada de especies endémicas que representa un $30 \%$ del número total de especies registrado, diez y siete nuevos reportes para Colombia, y veinte especies nuevas para la ciencia de estos bosques en años recientes. También hay 25 especies amenazadas de las mencionadas en el Libro Rojo de orquídeas de Colombia. Para la conservación de estas orquídeas se han establecido recientemente reservas naturales privadas como Morobia, municipio de Dagua, Peñas Blancas, municipio de Cali y La Irlanda, municipio de Jamundí en el Departamento de Valle del Cauca. En el departamento de Antioquia se estableció la reserva La Mesenia en el municipio de Jardín. La reserva natural privada La Planada en el municipio de Ricaurte, Departamento de Nariño se convirtió en reserva de la comunidad indígena Awa administrada por el Resguardo CAMAWARI. Las reservas naturales mencionadas integran sus esfuerzos de conservación de orquídeas con los de manejo de cuencas hidrográficas, ecoturismo, servicios ambientales y adaptación al cambio climático.

\section{Medicinal orchids of India and conservation measures for their sustainable management}

\section{PATHAK Promila}

Orchid Laboratory, Botany Department, Panjab University, Chandigarh - 160 014, India; ppathak_2000@yahoo.com

Orchids are the most pampered plants for their aesthetically beautiful flowers. and these constitute one of the highly evolved families of economically important plants, the Orchidaceae. Being rich in alkaloids, flavonoids, glycosides, and other phytochemicals, these plants have been used in the local system of medicine in different parts of the world since time immemorial. Numerical strength of orchid species in India has been catalogued as nearly 1,200 species; these are variously adapted to terrestrial, epiphytic, achlorophyllous, and mixed habit (as terrestrial and lithophytes) mode. In fact, Indian orchids have been used extensively in various indigenous systems of medicine since the Vedic period, and in the Vedic scriptures there is a mention of these plants under the name Vanda. Some of the orchid herbs including Malaxis acuminata, M. muscifera, Habenaria edgeworthii, and H. intermedia are highly valued in Ayurvedic system of medicine. The orchids have been reported to cure many ailments including cardiac (Eulophia dabia), dysentery (Satyrium nepalense), malignancy (Vanda testacea), nervous (Dendrobium nobile), orthopedic (Dactylorhiza hatagirea), respiratory (Dactylorhiza hatagirea), and rheumatism (Rhynchostylis retusa) disorders. A large proportion of orchid habitats have lost their character due to expanded agricultural and other developmental activities. Further, unregulated commercial collections have also affected the size and frequency of natural populations of several medicinally important orchid species. Though extensive research work is pursued on medicinal plants, in general, orchids 
have remained almost neglected in this direction. The present communication provides an account of some medicinally important orchids from India with their biological status and suggests both in situ and ex situ conservation measures for their sustainable management in the country.

\title{
Plan de manejo para la conservación de Cattleya quadricolor Lindl. en el Valle del Cauca, Colombia
}

\author{
Guillermo Alberto Reina-Rodríguez ${ }^{1,2^{*}} \&$ N. H. Ospina-Calderón ${ }^{3}$ \\ ${ }^{1,2}$ Consultor, Fundacion Gaia, Cali, Colombia; ${ }^{2}$ Departamento de Biología Vegetal, Universidad de \\ Barcelona, España; ${ }^{3}$ Programa de Ecología, Fundación Universitaria de Popayán, Colombia \\ *Autor para correspondencia: guireina@hotmail.com
}

Cattleya quadricolor es endemica a Colombia, presente en solo 3 departamentos (Valle del Cauca, Quindío y Risaralda), categorizada como EN en el libro rojo de plantas de Colombia (Calderon et al, 2007), y es una de las 22 especies de flora con mayor amenaza en el Valle del Cauca. Con este estudio, se generó el mapa de distribución actual y potencial de C. quadricolor, se evaluaron las condiciones ecológicas y demográficas en su habitat, y se identificaron las amenazas y fuentes de presión para su plan de manejo. Un total de $3.000 \mathrm{~m} 2$, fueron medidos, distribuidos en parcelas de $50 \mathrm{~m} \times 2 \mathrm{~m}$, en los que árboles y arbustos con DAP mayor o igual a $2,5 \mathrm{~cm}$ que hospedaran C. quadricolor fueron censados. Se contaron los individos sobre los forófitos detallando, estado reproductivo, número de pseudobulbos, altura sobre el forófito, angulo, posicion del forófito, entre otros. Los resultados demuestran la presencia de la especie en 16 municipios con un área de extensión de presencia de 234.359 Has. comprendidas entre los 930 y $1.450 \mathrm{msnm}$. Se demostró que $C$. quadricolor es más abundante al interior del bosque (55\%) que en árboles aislados (16\%) y sus densidades oscilan entre de 260 a $1.180 \mathrm{Ind} / \mathrm{Ha}$. Cattleya quadricolor crece sobre 20 tipos de forófitos, sin embargo 4 de ellos A. excelsum (37\%), G. ulmifolia (26\%), F. insipida (12\%) y E. ulei (7\%) y representan el $82 \%$ de la preferencia de esta especie. Se concluye que la estrategia de conservación in-situ debe incluir un incremento de la cantidad y la calidad del hábitat a través del manejo de sus cuatro principales forófitos, la consideración de las variables aqui medidas, el desarrollo de un protocolo de propagacion in vitro para su reintroducción, así como la disposicion de exedentes en viveros comerciales para restar presion en campo.

\section{Characterization of Brassolaeliocattleya Raye Holmes 'Mendenhall' - putatively transformed for resistance to Cymbidium mosaic virus}

\author{
Nyan Stillwell ${ }^{1}$, Heather McCafferty ${ }^{2}$, Yun J. Zhu² \& Ingelia White ${ }^{1 *}$
}

'Department of Natural Sciences, University of Hawaii - Windward Community College, 45 - 720 Keaahala Road, Kaneohe, HI 96744, USA; ${ }^{2}$ Hawaii Agriculture Research Center, 94 - 340 Kunia Road, Waipahu, HI 96797, USA; *Author for correspondence: ingelia@hawaii.edu

Orchids are infected by more than 50 different viruses. Infected plants bloom less efficiently, lack vigor, and produce lower-quality flowers than healthy plants. One of the most important viruses, with worldwide distribution, is Cymbidium mosaic virus (CyMV). It is a single-stranded, RNA virus belonging to the group of rod-shaped potexviruses. In previous research, a Brassolaeliocattleya orchid was transformed with the coat protein gene from Cymbidium mosaic virus using an Agrobacterium-mediated method. The aim was to improve resistance of the orchid to CyMV. Protocorm-like bodies of Brassolaeliocattleya Raye Holmes 'Mendenhall' were used. A full-length coat protein gene of CyMV was cloned into a vector, which 